\title{
THE TRADITIONAL RANKS IN THE PETRINE EPOCH: BETWEEN AFTERLIFE AND INNOVATION***
}

\author{
Andrei Zakharov \\ Chelyabinsk State University, \\ Chelyabinsk, Russia
}

The ranks and awards of Russian service elites and nobility have been a historiographical issue since the eighteenth century. G. F. Miller reflected on the psychology of the Tsar's subjects, who asked Peter the Great to keep some of the old ranks during the introduction of new ones and described two such cases. Soviet historians of the 1980s discovered several appointments to the old ranks made in the early eighteenth century and registered in archival documents. These curious cases were interpreted by researchers as isolated exceptions or the result of the inertia of old practices. The study of mass historical sources has since led to the discovery of more than 1100 cases of this kind and provided different contexts in which these awards were granted. It was previously thought that Tsar Peter ridiculed the old ranks, giving them only to his jesters. Modern research on Peter's innovations leads to a different view. For example, the introduction of the Hungarian dress and beard shaving was carried out in several steps, with backtracking. There has also been some oversimplification of the comparative pairs of epithets, such as "Muscovite-Imperial", "old-new", " and "boyars-nobility", which reflects nothing but the didactic attitudes of historians themselves. This article demonstrates that there was no dearth of official awards or withdrawal of the Duma ranks until the 1710s, at least. The introduction of The Table of Ranks did not abolish the ranks of "courtiers" (tsaredvortsy), as the earlier Muscovite ranks were called, which became the basis of the nobility. Peter I introduced several innovations to the traditional service hierarchy. Before the beginning of the Great Northern War, hundreds of the Tsarina's stolniki and court servitors were transferred to the Muscovite ranks, following which the Zhiletsky List continued being replenished for some years afterwards. The drama of ranks was aggravated by the enhanced status of the regular army ranks, which were outside the Moskovsky Spisok (the hierarchy of traditional ranks). The course of events was accelerated by the Tsar's intention to implement European analogues 42073 .

* This study was funded by the Russian Foundation for Basic Research, project 20-09-

${ }^{*}$ Citation: Zakharov, A. (2021). The Traditional Ranks in the Petrine Epoch: Between Afterlife and Innovation. In Quaestio Rossica. Vol. 9, № 1. P. 236-253. DOI 10.15826/ qr.2021.1.576.

Цитирование: Zakharov A. The Traditional Ranks in the Petrine Epoch: Between Afterlife and Innovation // Quaestio Rossica. Vol. 9. 2021. № 1. P. 236-253. DOI 10.15826/ qr.2021.1.576.

(C) Zakharov A., 2021

Quaestio Rossica • Vol. 9 • 2021 • № 1, p. 236-253 
of court and civil titles. Nevertheless, the popularity of the traditional ranks outside the army remained high. According to many sources, the traditional ranks of Muscovy were kept in check and re-registered throughout Peter's reign. The Tsar's decrees raised the status of military service. He sometimes approved petitions for the Duma ranks by several of his subjects and had his unique way of indicating the prospects for advancement to other petitioners. The low-level Muscovite ranks within the traditional hierarchy proved to be more stable than previously assumed. Muscovite ranks were not included in The Table of Ranks because the only rank of mass appointments by the early 1720s was that of a d'iak. Keywords: Russian history, nobility, Peter I, Moscow ranks, promotion in rank, Tsar's court, boyar lists

Чиновные отличия служилых людей и шляхетства интересуют историков с XVIII в., еще Г. Ф. Миллер размышлял о мотивах двух царских подданных, просивших старые чины у Петра I при появлении новых. Советские историки обнаружили в архивных документах еще несколько известий о пожалованиях начала XVIII в., которые трактовались как исключения или как проявление инерции старых практик. При обращении к массовым историческим источникам примеры таких пожалований умножаются, а контексты награждений оказываются различными. Петру I приписывается высмеивание старинных чинов - якобы он награждал ими только своих шутов. Современные исследования доказывают более сложную природу феномена нововведений. Красочные сравнения и определения «московское - императорское», «боярство - дворянство», «традиция - реформы» оказываются упрощенными и отражают дидактические установки историков и бытописателей. До 1726 г. производились награждения традиционными чинами. Царем принижался не статус думных чинов, а надежды знати на возобновление думных пожалований после награждения двух сановников 1709-1710 гг. Поэтому в качестве контрмеры царь пожаловал думным чином нескольких одиозных царедворцев и шутов, но одновременно удовлетворил и прошения о «популярных» чинах за заслуги. «Табель о рангах» не отменила чины «царедворцев» (московских чинов), впервые названных шляхетством в 1712 г. Петр I ввел несколько новаций в традиционную служилую иерархию. Перед самым началом Северной войны сотни стольников цариц и дворовых служащих были переведены в московские чины, затем несколько лет пополнялся «жилецкий список». Коллизию обострил возросший статус чинов регулярной армии, которые «московский список» не учитывал. Тем не менее, статус традиционных чинов вне армии сохранялся. Как показывают массовые исторические источники, на протяжении всего царствования Петра I продолжались учет и рекрутирование традиционных чинов Московского государства. Московские чины, стоявшие в традиционной иерархии ниже думных, оказались более стабильны. Они не были включены в «Табель о рангах», потому что единственным чином массовых назначений к началу 1720-х гг. оказались только назначения в дьяки.

Ключевые слова: история России, дворянство, Петр I, московские чины, чинопроизводство, царский двор, боярские списки 


\section{Historical context and sources}

In Muscovy, the top of the secular traditional ranks was occupied by those of the Duma: boyars, okol'nichii, dumnye dvoriane and dumnye d'iaki; the next level was occupied by komnatniye stolniki (spal'niki). And even lower, there were the Muscovite ranks or tsaredvortsy (courtiers): stolniki, striapchie, dvoriane moskovskie, d'iaki and zhil'tsy. In the early $18^{\text {th }}$ century, the Duma and Muscovite ranks had about eleven thousand members. According to Solovyov, there were also many other "rank circles" (chinovnye krugi) in the $17^{\text {th }}$ century [Соловьев, с. 375-376]: gorodovye ratnye, army regiments, strel'tsy, Muscovite prikazy, etc. These amorphous "rank circles" did not require radical reforms and could change borders and adapt to innovations. The Muscovite system of ranks was dualistic since noble families had the right to claim a rank for their status and were also given an opportunity to secure one for their service to the crown.

Records relating to traditional ranks in 1695-1721 were created by the Razriadnyi Prikaz (Military Service Chancellery) and Senate. Each element of the rank innovations introduced by Peter I was approved by the Tsar's decrees, which were entered in the Razriadnye Zapisnye Knigi "vsiakim delam" (Court Deployment Books of Different Acts) for future rank-awarding practice. Razriadnye Knigi 1698-1710 and annual Boyar Lists 1714-1719 have since been lost. Due to this fact, the reconstruction of the latest Muscovite awards offers a significant challenge. After the introduction of The Table of Ranks, traditional ranks were mentioned only as active or labeled as "old" and "former", as in the 1721-1723 skazky shlyahetstva (the nobility autobiographies). These three documents' groups are called mass historical sources, which were created annually or multiple. The documents of each group had a common origin, purpose, and formular.

A lot of Peter's associates began their career holding these former Muscovite ranks. In 1708-1713, out of eight governors only A. D. Menshikov boasted a non-traditional rank. In 1725, six out of ten governors held the komnatniy stolnik rank and four others held ranks such as boyar, stolnik, zhilets in the past ${ }^{2}$. Despite their appointment as governors, P. M. Apraksin and P. S. Saltykov were, at the same time, called blizhniye boyare (closest boyars) up until to their deaths. G. I. Golovkin held, for some time, both new ranks, such as chancellor and count, together with the old one of postel'nichiy. Those men who possessed old ranks and were familiar to the Tsar had much more opportunity to show themselves as suited to service, in contrast to unknown servitors. The Tsar's contemporaries noted that Peter was planning the ranks' reform in the early $18^{\text {th }}$ century [Грунд, с. 133-137],

\footnotetext{
${ }^{1}$ The data of lost books from 1697-1710 has been partly completed with the help of $18^{\text {th }}$ century copies of the documents.

2 The governors of the Petrine era included: boyar I. Iu. Trubetskoi, komnatnii stol'nik F. M. Apraksin, Prince M. V. Dolgorukov, Prince N. I. Repnin, Iu. A. Rzhevskii, Prince I. F. Romodanovskii, A. F. Saltykov, stol'nik A. P. Volynskii, zhil'ets P. V. Izmailov.
} 
seeking, at that time, the imitation of European titles. This initial plan was, however, prevented by the Northern War.

Bearing in mind this cultural and historical background, it is essential to understand how the picture of traditional ranks changed during the reign of Peter the Great. Was it about replacing some minor pieces of the puzzle, or even larger fragments? Or was it about laying new paint upon the old canvas? What were Peter's motives for the subsequent personal and mass appointments to traditional ranks? The answers to these questions are important for understanding the communication between a monarch and the Russian elite, and for discovering the destiny of existing institutions, which were prominent for the first hundred years of Muscovy.

\section{Historiography}

G. F. Miller was the first to pay attention to those among the Tsar's subjects who had asked Peter I to preserve the old ranks: "we should not be surprised sometimes at the immeasurable reverence for ancient rites, which is common to human nature. But when someone asks for some old ranks while holding new ones... such cases have drawn our attention and should not be hushed up" [Миллер, с. 205]. Miller knew of only two records of the Duma rank awarded in 1711 and 1725, which had been previously added to the Boyar Book of 1691/92.

This picture of the old ranks were supplemented by P. I. Ivanov and M. M. Bogoslovskii [Богословский, с. 243-258]. At the end of the twentieth century, an interest in the study of servitors' history was inspired by the work of R. Crummey [Crummey, 1974; Crummey, 1983]. A group of his followers has since set up a database, the "Duma Ranks Database", a fragment of which concerns the Duma ranks published by Marshall T. Poe [Poe, p. 346-380]. However, the formal statistics related to the Duma ranks, as suggested by Poe, ignores the peculiarities of the last boyar appointments. M. P. Lukichev noticed case within the duma appointments of 1712 and 1725, but he called them exceptional [Лукичев, с. 104-105; Медушевский, с. 160]. Later, six more appointments were discovered, which modern historians interpret differently. It appears that hundreds of people were appointed to the ranks of stol'nik, dvorianin moskovskii, and zhilets in the 1700s. Additionally, some of the Tsarinas' stol'niks were promoted to the Tsar's stol'niks.

Previous discussion of the Petrine reforms and the viability of the Muscovite institutions has relied more on new interpretations of long-known sources and secondary texts rather than on seeking out new historical documents.

Yu. M. Lotman and B. A. Uspensky have proposed a semiotic approach to interpreting the Petrine innovations [Лотман, Успенский]. This involves viewing ranks and institutions as elements of a process centered on encoding the myths born of real Petrine events in the later written tradition. They believe that the Tsar-reformer borrowed European and Latin names, replaced the Russian names of cultural institutions and toponymics, and introduced new facades but that, ultimately, he did not succeed in changing the essence of Muscovite institutions. 
According to Anisimov's description, "the Duma ranks were not formally abolished, but the appointments to boyars, okolnichie, etc. were sharply reduced, which meant the natural death of the Duma"; most of the Duma officials were assigned to service in various fields, in which they spared no effort, while the Duma ranks themselves were ridiculed [Анисимов, с. 480] ${ }^{3}$.

Modern historians criticize the view that there was a complete negation of the Muscovite institutions by the Tsar. P. Bushkovich and O. G. Ageeva, historians of the Petrine era, studying both the political and social history of the period, recognize the role of ranks for the elites and the monarch's wider subjects [Бушкович; Агеева]. But the destiny of traditional ranks as social institutions has not yet been clarified. There are some ways to resolve the issue. Firstly, to reconstruct all the cases of traditional appointments in the context of social history and prosopography. Secondly, to understand the impact of these appointments on the ranks' owners themselves. Thirdly, to evaluate the social significance of these requests for the old ranks, the government's measures in response, as well as Tsar Peter's own reaction.

\section{The first rank experiments of Peter I}

In the 1680s, the number of men who served in the duma ranks totaled about 170 [Poe, p. 254-315]. The Coup of August 1689 immediately caused an increase of rank appointments. By 1694, 28 close associates of Peter the Great ${ }^{4}$ or those with connections to the Naryshkins were rewarded with duma ranks. The Naryshkin faction among the duma ranks had a numerical superiority of 7 appointments in 1695-1699. That list included three persons of the Prince's and the boyar's clans, two "sluzhilye liudi" (noblemen) and two d'iaks.

For the first time, by Peter's initiative, duma ranks were given to his active allies, and not just to the Tsar's relatives. Posol'skii d'iak (ambassador's d'iak) Vinius became the first to receive a Duma rank on 24 March, probably due to the fact that he had succeeded in carrying out royal assignments and had taught the Tsar to speak Dutch. It was the first decision by Peter taken on his own initiative. The son of Dutchman was one of many "rankless" among the Tsar's retinue during the first Arkhangelsk campaign of 1693 [Двинской летописец, с. 194]. On obtaining his new rank, Vinius was present in the Duma from 1698-1701 [Захаров, 2009, с. 101-103].

The leaders of the Azov-Dnepr campaigns of 1695-1697 also drew the Tsar's attention and became owners of duma ranks ${ }^{5}$. The heroes of Azov

${ }^{3}$ The historian cannot substantiate the sequence of actions (whether appointments were the first to be stopped, or the Duma Assemblies were put to an end), as well as the date of the Duma Assembly's termination.

${ }^{4}$ After the insurrection of 1689, the Naryshkins were appointed to duma ranks six times. Their relatives-in-law Lopukhiny - twice. In summer and autumn 1691, V. F. Naryshkin was made okol'nichii and boyar.

${ }^{5}$ Prince P. G. Lvov (okolnichiy since 15 August 1696, and former stol'nik), Prince Ya. F. Dolgorukii (boyar since July 201697 , and former spal'nik), S. I. Yazykov (okol'nichii since 25 March 1697, and former dumnyi dvorianin), V. B. Bukhvostov (okol'nichii since 28 August 1698, and former dumnyi dvorianin). Okolnichii I. A. Musin-Pushkin was appointed to the boyar ranks on 9 September 1698 for his service in Astrakhan. 
were, thus, duly rewarded. Within a year, Prince P. G. Lvov, S. I. Yazykov, and V. B. Bukhvostov had seats in the Duma [Захаров, 2009, с. 99-100, 161-162, 275-277]. During the Azov campaigns themselves, the Tsar was not ready to appoint orders and new ranks, but Russian elites were unwilling to accept any other forms of reward than those traditionally bestowed. The duma rank was prestigious and promised pozhalovaniia (money and land) for the recipient. But the actual number counselors of Duma in 1697-1701 did not exceed $42 \%$ of those who had duma ranks [Там же, с. 395-398].

As is known, two new Muscovite awards were added to the traditional rank hierarchy after the end of the Great Embassy in 1697-1698. Peter the Great established the new rank of dumnyi sovetnik (Duma Councilor). This new honor was conferred on P. B. Voznitsyn on 15 July $1699^{6}$ for his service as Great Ambassador. Establishing the new rank, the Tsar followed in his predecessor's footsteps ${ }^{7}$. A few months later, Voznitsyn was granted the traditional a rank-position of patriarshii boyarin (the Patriarch's boyar) by decree on 10 December $1699^{8}$. The appointment appears particularly honorable since that status had previously been achieved by the Okol'nichiy, M. I. Glebov, who later lost the position of patriarshii boyarin and was sent by the Tsar to Azov to serve alongside his son, Leontiy. A year later, the Tsar allowed Glebov to return to the capital. In the meantime, Peter was searching for a candidate to head the Monastyrskiy prikaz. However, Voznitsyn fell ill in early 1700 and died on 4 February $1702^{9}$.

The new ranks and related terminology were incorporated into official documents surprisingly quickly. Take, for instance, boyar B. P. Sheremetev, who, while staying on the island of Malta in 1698, was granted the new honorary status of "Kavaler Maltiyskii" ("chevalier of Malta") on 19 January 1699. This title stood in contrast with any other. After the Tsar's decree of 10 January 1699 [РГАДА. Ф. 199. Ед. хр. 130. Ч. 15. Д. 3. Л. 3 об.]. В. P. Sheremetev was mentioned as a "General and Military Chevalier of Malta" in all documents. Of course, not all the Tsar's experiments took root. The first and the only time komnatnyi stol'nik N. I. Repnin was acknowledged as a "general rydenbant" of St. Andrew was in 1711 [Захаров, 2003-2020; РГАДА. Ф. 210. ОП. 2. Д. 58. Л. 2, 5, 9].

Thus, for the first time, a servitor's and aristocrat's personal service became the main reason for a rank appointment in 1695-1699. The Duma ranks entitled one to take part in the Boyar Duma, they did not necessarily move the Tsar to immediately include the honoree into their real circle of counsellors.

\footnotetext{
${ }^{6}$ The Tsar's decree of 26 June 1701 specified the place of the new rank in the accepted hierarchy: "elel v boiarskikh knigakh i spiskakh i vo vsiakikh pis'makh pisat' evo s vichem vyshe dumnykh d'iakov" [РГАДА. Ф. 210. Оп. 2. Д. 45. Л. 10].

${ }^{7}$ For example, Tsarevna Sophia bestowed the specially invented rank of dumnyi general on colonel A. A. Shepelev in 1682/83.

8 "Velikiy Gosudar' ukazal 'atriarshego Rozryadu na mesto Glebova vedat' dumnomu sovetniku Voznitsinu i imia pisat' dumnym sovetnikom I patriarshim boyarinom" [РГАДА. Ф. 199. ЕД. хр. 130. Ч. 15. Д. 3. Л. 28 об.].

${ }_{9}^{9}$ Voznitsyn was invited to the Duma for the first time on 14 October 1699 [Захаров, 2009 , c. 106].
} 


\section{The Renaissance of the Duma ranks and a pure parody}

The traditions of rank appointments continued to be in accordance with duma rewards of the $18^{\text {th }}$ century. Take, for example, Ivan Ivanovich Islen'ev's appointment, which occurred during his campaign to Voronezh, coinciding with his birthday on 30 May 1701. Islen'ev came from a noble family, but his parents and ancestors were not appointed higher than the rank of stol'niki. Having a rank of stol'nik, he was also a voivod in Murom, Alatar' and, possibly, in Shatsk. As a voivod of "little" towns, Ivan Islen'ev unexpectedly became Peter's komnatniy stol'nik in $1685 / 86$. Only children of aristocrats, relatives and cousins-in-law were previously given this court rank. Isleniev's sister-in-law (svoyachenitsa), Akulina Semenovna Chaplina, was married to Peter's second cousin (trojurodnyi dyadya), K. F. Naryshkin [Руммель, Голубцов, с. 647]. This is likely why the unknown Islen'ev managed to become Tsar's komnatniy stol'nik, and later rose to the rank of dumnyi dvorianin in 1701. In 1702, Islen'ev, travelling among a group of courtiers led by the Tsar, went to Arkhangelsk and the Solovetsky Monastery [Досифей, с. 100] and died in 1703 [РГАДА. Ф. 210. Оп. 2. Д. 49. Л. 7].

A month after Islen'ev's elevation in rank, on St. Peter's day (the Tsar's name-day celebration), the dumnyi dvorianin rank was received by "kniaz'-papa vseshuteishego sobora" N. M. Zotov, who used to teach the heir to the throne to read and write. Zotov was appointed as a judge of the Pechatnyi prikaz instead of pechatnik (keeper of the Seal) D. M. Bashmakov on 29 June 1701 [Там же. Д. 45. Л. 8]. The reasons for rank rewarding in 1701 are described in the Decree about Count title 1710 (draft): "[In honour of] his great loyalty, eagerness and cleverness he should be accepted to our privy council. His advice given to the Tsar during the Turkish war was very useful, that is why he was appointed dumnyi $d v o-$ rianin and pechatnik ranks" [РГАДА. Ф. 154. Оп. 2. Д. 68. Л. 2 об.]. The rank of dumnyi dvorianin was given to Zotov four years later, after the end of his Azov service, which points to the fact that he asked for his duma rank personally.

At that time, the Duma itself was going through significant changes. After the spring of 1702, the boyar prigovory (orders), as well as the motives for assemblies of all the Duma ranks remaining in Moscow are unknown. In the capital, several boyars were beginning to work as Boyar Commissions (with 1706 - "Consilii"). There was no need to issue new ranks in order to expand the narrow circle of the advisors. Therefore, after Islen'ev and Zotov's promotion, nobody was added to the list of duma ranks for the next eight years leading up to the Poltava victory.

Appointment to the duma ranks as a reward was started again with Prince A. D. Menshikov's letter to the chief of Razriadnyi prikaz (The Military Service Chancellery) boyar, T. N. Streshnev. Vasilii Yershov, as Menshikov's subordinate, was given a duma d'iak rank in 1709 and for the first time 
written in the Boyar List [РГАДА. Ф. 210. Оп. 1. Д. 11. Л. 47] 10: "oktiabria $\checkmark 15$ den' ukaz o tom za rukoiu boiarina Tikhona Nikiticha Streshneva" (There is an order from 15 October under the signature of boyar Streshnev) [РГАДА. Ф. 210. Оп. 2. Д. 56. Л. 8 об.]. Afterwards, there was a note: "Ро pismu ot svetleishago kniazia. Oborkamisar ot kovalerii" (By the letter of his Highness. [Yershov] Ober comissar ot cavalerii).

The next notable grant of rank could not have taken place without the Tsar's will. On 22 January 1710, Peter the Great promoted the Kazan Governor okolnichy P. M. Apraksin into the boyar rank [Там же. Л. 2 об.]. Among the three senators who had previously been in the boyars, he was the only one called "blizhnii boyarin, graf" up to his death [РГАДА. Ф. 248. ОП. 12. Д. 641. Л. 38] ${ }^{11}$. This designation emphasized respect for the old ranks. Such rank-awarding revived the expectation of the Duma ranks being accessible once more, however, the Tsar checked the subsequent wave of petitions in an unusual way.

New owners of the desired ranks were people of different social status, from active courtiers to jesters [РГАДА. Ф. 210. Оп. 2. Д. 56. Л. 2 об., 4 об.; Д. 58, Л. 2, 6 об.]. One of the organizers of the "vsep'ianeishii sobor" (most desperate and all-pervasive assembly) was Prince Iu. F. Shakhovskoi (Arkhid'iakon Gedeon), who convened the courtiers ("soboriane"). He was suddenly declared a boyar from his former rank of komnatniy during Bright Week on 12 April 1710. Almost all of the major associates of the crown, including the Tsar himself, were acknowledged among the "soboriane". The motive for possessing such a rank seems to be obvious. His father, Prince Fedor Ivanovich, reached the same level in September 1682. Diplomat Prince B. I. Kurakin appreciated Shakhovskoi's controversial talents as a man of "uma nemalogo i chitatel' knig, tokmo samoi zloi sosud i p'ianoi" (a great mind and a book reader, and the most evil and drunk person) [Грунд, с. 129; Куракин, с. 256]. Attempts to draw a clear distinction between the jester and the servant in the context of the "soboriane" actions are futile - it was intentionally erased. On the same day as Prince Iu. F. Shakhovskoi, the duma ranks were awarded to ordinary jesters. K. Kh. Patrikeev ("Otets Koz'ma") "iz blizhnikh liudei" was awarded the okol'nichii rank and stol'nik P. V. Buturlin ("Korchaga") the dumnyi dvorianin. In the $17^{\text {th }}$ century, the Tsar could not give the okolnichii rank to anyone except for his wife's relatives. In Peter's letters and diaries and campaign diaries only five people were named "duraki" (that is, jesters) [Письма и бумаги, 1992, с. 294; Походный журнал, c. 108] ${ }^{12}$ : K. Kh. Patrikeev, P. V. Buturlin, P. A. Ushakov, Alexander Uishkov and S. Turgenev. The service of three "new boyars" was not limited

${ }^{10}$ The information about V. Yershov given by Marshall Poe is $\mathrm{t}$ mistake. Yershov did not hold the rank of duma d'iak from the 1690; his name was included in Boyar Book for $1691 / 92$ only in 1711 when he was given "oklad" 250 roubles [Poe, p. 406].

${ }^{11}$ P. S. Saltykov was also called "blizhnii boyarin" until his death.

${ }^{12}$ The documents mention "tsarskii durak" (tsar' jester) Semen Turgenev, but this person is still not identified with stol'nik S. Ia. Turgenev. 
to their ability to amuse the Court. Thus, Prince Nikita Zhirovoi-Zasekin had been a voivod of Kostroma province since 1719 [РГАДА. Ф. 199. Ед. хр. 130. Ч. 16. Д. 6. Л. 5; Ф. 350. Оп. 3. Д. 1. Л. 98]. Prince Iu. F. Shakhovskoi, P. V. Buturlin, and okol'nichiy Prince Iu. F. Shcherbatov, in accordance with the Tsar's order of 16 August 1710, described and measured lands and forests in the outskirts of the capital and across Russia. Prince Shakhovskoi put in great efforts to protect the Admiralty Island from fires in 1711-1713 [НИА СПбИИ РАН. Ф. 83. Оп. 1. Д. 3762].

The rank of A. A. Iushkov was not treated as a jester's reward. While rewarding A. A. Iushkov on 4 November 1711, Peter the Great personally wrote in an order the following: "Za mnogiia i chrezvychainyia sluzhby u sluzheniia i radeniia v vruchennykh emu delekh pozhalovat' seiu chestiiu" (The person is awarded a rank for his activities and state service) [Письма и бумаги, 1964, с. 236; РГАДА. Ф. 210. Оп. 2. Д. 58. Л. 4 об.]. Alexander Iushkov, a person bearing the same family name, was Peter's jester. Historian M. M. Semevskii believes that Aleksey Iushkov secured his rank with the help of Tsarina Praskovia Fedorovna, who was trying to save his son - the Tsarina's kravchei, Vasiliy - from her furious father [Семевский, с. 23-24]. Aleksey Iushkov took part in three campaigns in the $18^{\text {th }}$ century, but he also missed three others by paying money to the crown instead [РГАДА. Ф. 210. ОП. 2. Д. 50. Л. 49]. In 1705, he was sent to be a voivod in Belev for several years. In 1711, despite his age, he continued his service (" $v$ Armii") as a chief of "emergency affairs" [Там же. Д. 52. Л. 24; Д. 58. Л. 22 об.]. In December 1712, he began to receive a salary of 350 rubles, one of the most important pieces of evidence, which proves he was given his rank as a reward for service [РГАДА. Ф. 210. Оп. 1. Д. 11. Л. 39]. There were many people in service, like Iushkov, who deserved high ranks, but not everyone enjoyed the Tsarina's favour.

Odious "soboriane" - jesters were appointed according to the Tsar's efforts to discourage noblemen's desire for duma ranks after the appointment of Ershov, Apraksin and Iushkov. Those who aspired to high rank were taught a new lesson by Tsar. Prince Ivan Alekseevich Golitsin was made boyarin. On 14 October 1715, the Tsar sent a decree to Prince M. V. Dolgorukii. The decree was full of scathing sarcasm [РГАДА. Ф. 9. ОП. 1. Д. 9. Л. 49-49 об.]. It is an instructive example of a husband receiving high rank in exchange for a wife's service [Захаров, 2013, с. 29] ${ }^{13}$. What is more, the Tsar's decree was read by jester Ekim Volkov, nicknamed "Komar" (Mosquito), not by a senator or d'iak as it was usually. As a result, Ivan Golitsin was ashamed. In 1722, he admitted that he had never been in military service [РГАДА. Ф. 286. ОП. 1. Д. 7. Л. 24]. The prince always referred to himself as a komnatniy stol'nik (courtier), but the senators intentionally named him a boyar, in line with the Tsar's desire to remind everyone of Prince Golitsin's "worthy" achievements [РГАДА. Ф. 248. Оп. 3. Кн. 95. Л. 192-194].

${ }^{13}$ Princess A. P. Golitsyna, nee Prozorovskaia as the "shutikha" (she-jester) of Tsarina Catherine I, participated in the amusements of the "soboriane" in the role of "kniaz' - igumen'i". 
Similar comic nicknaming took place together with official titles several times. In 1716, the aged N. M. Zotov had to accept his new rank "Tainyi sovetnik i Blizhnei kantseliarii general prezident, graf Magnus Naklevanii” (Privy councillor and administrative office general President, Count Magnus of Naklevania. Naklevania - Russian spoken form "to have a cat-nap") in the midst of "soboriane's" meetings. This new title was mentioned again and again in official senate's papers [РГАДА. Ф. 248. Оп. 12. Д. 641. Л. 39] since, at the time, it was not necessary to draw the line between official rank and humorous honorific.

The list of those who were elevated to high rank before and after the victory of Poltava consisted of people of different status. There were influential officials (V. S. Yershov, P. M. Apraksin), service men (A. A. Iushkov), and courtiers (Prince Iu. F. Shakhovskoi), for whom the rank was a way to increase personal status and that of one's family. The Tsar's jesters got their high ranks as an edification for dreamers of the boyar ranks. The rank was, thus, a kind of a honour even for jesters.

Following the request for the boyar ranks by the nobility, the Tsar began a transfer of several aristocrats from the old ranks to some new positions. So, T. N. Streshnev was transferred from the boyar rank to the rank and status of taynyi sovetnik (Privy Councillor) in response to his Senate appointment. The transfer being confirmed by a rare document on 22 March 1711. From that time on, Streshnev ceased to be called boyar [РГАДА. Ф. 1209. Оп. 4/1. Д. 4719/17. Л. 39]. Fifteen years later, a petition arrived from another dignitary. Boyar A. P. Saltykov, in which he begged Empress Catherine the First for the new rank of deystviyel'nyi taynyi sovetnik (Full Privy Councillor). He wrote: "And I, a slave of yours, have not been awarded for my service, unlike my brothers ("protiv moej brat'i ne pozhalovan"). I served your father, Great Sovereign, and Your Imperial Majesty for 63 years” [РГАДА. Ф. 9. Отд. 2. Оп. 4. Д. 82. Л. 419-421]. The attitude of the old boyars to the new rank system changed gradually, without resistance and even with a request to new rank "like my brothers" ("protiv svoej brat'i").

And traditional ranks continued to be a way to bestow honour even after Peter's reign. Catherine I elevated stol'nik S. P. Neledinskii-Meletskii to the rank of boyar for his long service on 15 September 1725 [РГАДА. Ф. 210. ОП. 1. Д. 11. Л. 31]. It is more likely that this appointment can be explained by his petition. However, the abolishment of the appointing practice in the Duma was in 1701-1702. Traditional ranks as awards continued for at least another 12 years.

\section{The last Muscovite appointments and servitors' fates}

Since 1696, Peter the Great was the only person who had the right to appoint high ranks. After his co-regent, Ivan V's, death, Peter incorporated Ivan's courtiers to his own court. Tsar Peter refused to appoint komnatniy stol'nik (or spal'nik - a high rank of courtier), since all previous appointments of that kind were issued by the two Tsars together. The last to become a komnatniy stolnik (spal'nik) were V. M. Rtishchev (14 Octo- 
ber 1695) [РГАДА. Ф. 210. Оп. 2. Д. 36. Л. 369 об.] and the above-mentioned Prince Iu. F. Shakhovskoi $(1696 / 97)^{14}$. Their subsequent fates were, however, very different.

Iu. F. Shakhovskoi successfully served as Court servitor. He, together with the razriad men, arranged the wedding of the jester Filat Shansky in 1702, and the visits of Peter's company to the svyatki $i$ slavleniia (Yuletide for glorification) in 1710 [РГАДА. Ф. 210. Оп. 8. Д. 1098. Л. 77; Оп. 17. Д. 8]. Some historians consider him to be a jester, in accordance with Prince B. I. Kurakin's opinion, although his actual role was that of the buffoon organizer. V. M. Rtishchev was not as successful at Court or in military service. Rtishchev was granted the rank of major in 1708 but remained under suspicion from 1715, following his marriage to the daughter of Senator Prince G. I. Volkonsky, who had fallen out of favour. Therefore, until the Tsar's death, Rtischev did not advance in his career. The Rtishchevs' relatives were the Tolstoys. Rtishchev's sister Praskovia was married to Ivan Tolstoy, Count P.A Tolstoy's son, but that relationship could not save him from disgrace in the eyes of the Tsar.

In total, 80 men who were once appointed to the rank of spal'niks were still alive by 1721 . Their social status after the termination of the rank-awarding practice is worth exploring. One can differentiate between two subgroups: those who had experience of service in the regular army, and those who remained outside of military service and its ranks. Entry into the "poteshnye" or Guards regiments was sufficient to continue into regular service (" $v$ regulyarstve"). By 1721 , forty-two spal'niks (52,5\%) had been given a military rank or had served in the army. In other words, this old rank had not been included in The Table of Ranks nor had it been cancelled either. There are 32 detailed documents from 1720-1722 referencing spal'niks. In $82 \%$ of these cases, the beginning of service was associated by the men themselves with their having obtained a Muscovite rank in the 17th century. Two or three decades later they perceived their spal'nik rank as having been granted in return for a high level of service in the past. By the Tsar's decrees of 1712-1714, 93 families from among the spal'niks were obliged to move to the new capital, to Kotlin Island, by the end of the Northern War. According to the 1716 Senate list, 69 spal'niks were to move from Moscow to Saint Petersburg, of which 33 already owned houses in the new capital [РГАДА. Ф. 248. Оп. 12. Д. 641. Л. 13-17]. Only five spal'niks served in the $18^{\text {th }}$ century prikazy, which is similar to the situation of the previous century. In 1710-1722, twenty former spal'niks held the higher provincial positions. In 1725, six out of ten governors formerly served as spal'niks, and three became vice-governors.

Spalniks held administrative, military, and diplomatic positions, extraordinary commissions that required education, connections and their horizons to have been suitably broadened. The Great Embassy of 1697-1698

${ }^{14}$. His namesake, who was a captain and died no later than 1710 , is a known spal'nik [РГАДА. Ф. 210. Оп. 2. Д. 41. Л. 15 об., 76 об.]. And his namesake [Там же. Д. 41. Л. 76. Д. 43. Л. 69, 417. Д. 45. Л. 595, 747, 776 об. Д. 56. Л. 85]. 
affected the cultural and educational level of 61 participating spalniks. A quarter of them continued their careers in the diplomatic service or in the Navy. This range of opportunities was acquired partly via European experience [Захаров, 2016].

Only a handful of spal'niks kept their positions in the court service in the first decade of the $18^{\text {th }}$ century. They were the Apraksins, the Naryshkins, and the Saltykovs, as the Tsarevnas' relatives. The Tatischevs, Iushkov, and Izmailov were Tsarevna Praskovia Feodorovna's stol'niks. There was also Prince M. M. Obolensky, a servant of Tsarevna Maria. At the same time, Prince F. S. Khovansky and I. P. Matiushkin remained the only spal'niks in Moscow to participate in the "hod za ikonami" (for church ceremonies). Prince Khovanskii was the grandfather of Iakov and Sergei Vasilyevich, the Siberian Tsarevichs, while Matiushkin was the Tsar's cousin. Four people were disgraced. Only V. B. Sheremetev was punished for misconduct in the service. The sentences issued in the Tsarevich Alexei case were harsh: A. F. Lopukhin was executed, while S. G. Naryshkin and I. I. Naryshkin were sent into exile [Бушкович, с. 403, 429]. The recruitment of spal'niks into regular military service in the early $18^{\text {th }}$ century, and their appointment as officers to the Guard regiments, were the main factors in the rank's erosion. The court status of spal'niks, more pronounced in the $17^{\text {th }}$ century, was almost lost. Nevertheless, the holding of the spal'nik rank in the past would still offer a significant boost to one's military career in the regular army and in the provinces.

Appointing traditionally lower ranks (stol'nik, stryapchii, dvorianin moskovskii, zhilets) had its own features. In accordance with the boyar lists, in 1700 there were many "records" (promotion from Dvortsovyi ranks to Muscovite ones) and several individual Muscovite appointments. The Tsarinas' stol'niks as a dvortsovyi rank were not sent to regimental service according to Muscovite Court traditions. Therefore, shortly before the Northern War, 169 of the Tsarevna's stol'niks were promoted to the Tsar's stol'niks ${ }^{15}$. Among them were the famous V. N. Tatishchev, and the Siberian and Moscow governor, A. L. Pleshcheev.

There are 46 skazki, dating back to 1721-1722, by Tsar's stol'niks, who had been given ranks in 1700. Most of new Tsar's stol'niks - 40 men (87 \% of the sample) turned out to be in the regular service as officers after their training in "soldatskomu stroiu" (soldiers' formation) during the first decade of the Northern War. So, 24 stolniks were awarded officer ranks in 1700 , and five more went to the Narva campaign in the "Bol'shoi Polk" (Big regiment) of the boyar, F. A. Golovin. During 1701-1706, 10 more people were enlisted as officers. Four men were not awarded the officer's rank and ended up in the Dragoons for failing to attend the Smotr (Insurrection). The transfer of the Tsarinas' stol'niks to the Tsar's stol'niks in 1700 provided obvious advantages for obtaining an officer's rank in the army.

${ }^{15}$ On 19 August 1700, 169 people were "veleno napisat' v polkovuiu sluzhbu” (ordered to be written into regimental service) asistol'niks. 
In the same year, one hundred and two court servitors ${ }^{16}$ (Dvorovye striapchies, klyuchniks, and charochniks, controlled by the prikaz Bolshogo Dvortsa) were transferred to the moskovskie dvoriane (i. e. the penultimate Muscovite rank). Former Dvorovye turned out to be an old layer, and most of them soon died or were retired $(44 \%)^{17}$. There were no less than seven men in military service, six men were marked as "v posylkakh po delam" from prikazy, and voivodes - two. However, 16 moskovskie dvoriane returned to Court rank between 1701-1703, and for other reasons, 8 men lost the benefits of Muscovite service ${ }^{18}$. The status of moskovskie dvoriane gave some servitors the opportunity to leave the Court service, to achieve the Voivodeship or military rank.

Seven servitors and one foreigner were appointed to the stolniks by special decrees, which was a proven practice of the $17^{\text {th }}$ century. Thus, Prince Andrey Vasilievich Svirskii from the Polish-Lithuanian Commonwealth was included in the list of stolniks on 30 November 1699. In 1700, some of the Tsarina's stol'niks were added to the Tsar's list on an individual basis. Among them, there were such people as Prince I. P. Meshcherskii (added on 22 January), I. M. Yeletskii (26 January), P. I. Lovchikov (28 January), M. S. Anichkov (3 February). The brothers zhil'tsy, Ivan Srednii (the Middle) and Ivan Bolshoy (the Senior) Il'ich Dmitriev-Mamonov, were made stol'niki on 14 December 1699. The latter, the Senior Dmitriev-Mamonov, was known as a guard officer and morganatic husband of Tsarevna Praskovia Ivanovna (1724). In 1702, striapchii S. M. Durov was made the latest stol'nik $^{19}$. It is possible he was awarded for voivodstvo in Ol'shansk.

The next rank, the dvorianin moskovskii, was given to eight people: a Turk, V. I. Serdarov ("iz turchan"), four Russian gorodovye dvoriane and three non-servitors in $1700-1713^{20}$. F. I. Iavorskii, a brother of the Metropolitan " $u$ riazanskogo mitropolita $v$ domovykh liudiakh", was appointed to this rank on 1 December 1701 [РГАДА. Ф. 210. Оп. 2. Д. 45. Л. 289]. Nedorosl' (greenhorn) Ivan Plokhoi was included in the Boyar List of 1707, because of his physical disability ("za uvechem, chto gorbat") and, more importantly, his father was the striapchii s kliuchom, L. В. Plokhoi [РГАДА. Ф. 210. Оп. 2. Д. 53. Л. 121] $]^{21}$. According to the letter of Prince Ia. F. Dol-

${ }^{16}$ On 27 May 2700, 100 courtiers ("100 dvorovykh liudei, kotorye ot dvora otstavleny i prislany dlia sluzhby $v$ Razriad... a $v$ Razriade napisany oni po moskovskomu spisku") were dismissed from court service and sent to work in Razriad... and in Razriad they were registered in the Boyar Lists (i. e. as dvoriane moskovskie).

${ }^{17} 35$ people died between 1700-1713. 19 people were dismissed, half of whom died before 1713 .

${ }^{18}$ Two people were demoted to the gorodovoi rank, two people were sent to the "Dela Dvortsa" (Court's business), two went to the monastery, two people were exiled into Azov.

${ }^{19}$ But there were not any records of Durov's appointment day.

${ }^{20}$ In 1700 there were the following appointments: V. I. Serdarov (28 January, Prince I. V. Shakhovskoy, vybornyi dvorianin, Prince P. B. Shakhovskoy (2 March; G. I. Dernov (10 March 1701); “iaroslavets” І. I. Tikhmenev (1709) [РГАДА. Ф. 210. Оп. 2. Д. 43. Л. 658, 641 об.; Д. 45. Л. 293; Д. 56. Л. 182].

${ }^{21}$ The appointing Decree included a note: "pometa na smotrennykh tetradiakh u zapiski nedoroslei" (a note on examined papers for minors' registration). 
gorukov and Count I. A. Musin-Pushkin, the Tsar granted the rank of dvoriane moskovskie to 35 year old Nikon Ivanovich Volkov in July 1713 ("Tsarskoe velichestvo ukazal po imennomu svoemu v. g. ukazu... napisat' vo dvoriane") [РГАДА. Ф. 286. Оп. 1. Д. 5. Л. 142]. He was an eminent merchant ("kupchina") and had been serving Tsarevna Nataliia Alekseevna since 1704 [Там же. Д. 7. Л. 1163]. These two appointments would not have been possible without the Tsar's intervention. It is reliably known that Peter the Great took part in the examination of "tsaredvortsy" (courtiers) and marked with pencil their appointments himself.

Peter I continued to introduce new titles and ranks in the 1700s. A higher position than d'iak was taken by "general'nyi pisar' i sekretar"' (general clerk with secretary rank) in 1702. D'iak Liubim Sergeevich Sudeikin was the first person to receive such a sekretar' rank in Russia. Prince M. P. Gagarin became "general'noi president, moskovskoi commeandant i sibirskikh provintsei sud'ia" (1707) and A. A. Kurbatov gained the rank of "ober inspektor Ratushskogo pravleniia" (City Hall administrator), which later became a permanent position (1706) [РГАДА. Ф. 210. Оп. 2. Д. 46. Л. 291; Д. 53. Л. 33 об.; Д. 55. Л. 227]. The senators were inscribed into the Boyar List with their new rank, excluding those men with traditional ranks from all ranking rubrics. In senators' cases, a process of equation between traditional ranks and the new position of senator occurred. Later, d'iaks were renamed secretaries. Regular appointments to the rank of prikaznyi d'iak still took place as the Northern War began. During the period 1700-1712, 104 prikaznye podd'iachie were made d'iaki [Захаров, 2003-2020].

There were many appointments in the lowest Muscovite rank of zhiltsa in 1700. About 400 men were appointed " $v$ zhit'e", including 130 dvortsovye podkliuchniki [РГАДА. Ф. 210. Оп. 3. Д. 69. Л. 77-92 об.; Д. 58. Л. 208$212]^{22}$ placed in the Zhilets List by royal decree on 28 August 1700. 107 men were appointed to the rank of zhilets during 1701, 117 - in 1702, 80 servitors - in 1703, 4 - in 1704 [РГАДА. Ф. 210. ОП. 3. Д. 60. Л. 193200 об.; Д. 70. Л. 277-290 об., 324-329 об.; Д. 69. Л. 108, 110]. The service of their fathers, who had been retired for old age or illness, was the primary argument for a noviki's appointment (young and new servitors) - they became zhilets. Therefore, among the group of noviki, there are typical examples of those granted oklady (a new entitlement) or delays from service for a few years for young zhiltsy. Other men were recruited in training for the regimental service. In the early $18^{\text {th }}$ century, Muscovite ranks from a Tsar stol'nik to zhilets offered such a reward and a way to transfer persons from Court service to military.

Muscovite ranks were not included in The Table of Ranks, because the only rank of mass appointments by the early 1720s was in the d'iaks' appointments. This rank was replaced in 1722 by the rank of secretaries [Серов, с. 70].

${ }^{22} 414$ people were inscribed in Zhilets List for 1704 in the rubric "zhiltsy s 1700" (men were appointed to the zhilets rank), including 63 men from podkluchniki. 
Traditional ranks were a variant of the representation of the Muscovite elite's status. They are a reflection of "the old" and "the new" in the vocabulary of prikaznye documents, of the self-identification of men, of the aspirations of the nobility, and of the supreme power of the crown in the Petrine epoch. Simple interpretations of traditional ranks as the "remnants", "formalities" or "exceptions" from before the proclamation of the Russia Empire are wholly unsuitable and fail to appreciate the importance of the Muscovite heritage for Peter the Great.

Duma ranks continued to be an award for the most successful servitors in 1695-1701, and immediately provided seats in the Boyar Duma. The main reason for rank appointment became the honoree's personal service. After the completion of assemblies of all staff of the Duma in 1701-1702, a rank awarded for the Boyar Duma lost its meaning, but the potential for ranks as a reward for service was not exhausted.

In the first decade of the $18^{\text {th }}$ century, the Tsar introduced six new rankawards to the "Rank Moscow List" ("moskovskii spisok"). And five Tsar confidants and administrators were rewarded for their service with entry to the duma ranks before the establishment of the Senate. About 1112 people were appointed to the Muscovite ranks in 1700-1713. It is clear that the Tsar did not rush to make a choice in favor of European ranks at this time. The necessity of honoring the service of his closest associates was obvious to the elites and the "Tsar the reformer" alike. Maintaining traditional ranks was influenced by the need to maintain the stability of the Razriadnyi prikaz (later Razriadnyi stol of the Senate), which continued to organize nobility service. Some administrators who possessed traditional ranks or enlisted the support managed to gain Duma ranks before and after the victory at Poltava. Therefore, the Tsar immediately awarded to "soboriane-jesters" by duma ranks than were supposed to prevent noblemen's desire for boyar rank. But the Tsar did not see any reason to ridicule Duma ranks in the first decade of the $18^{\text {th }}$ century.

By the early 1720s, the government adapted the existing Muscovite ranks to facilitate the recruitment of court servitors to the army and other (non-serving people) for civil affairs. Military ranks were used in the $17^{\text {th }}$ century, but new civil titles and positions were introduced within the Muscovite ranks and Administrative Paper in the first decades of the new century. Contemporary historians, familiar with The Table of Ranks, may have considered Peter's early rank reforms as unimportant. However, in the early $18^{\text {th }}$ century, these changes seemed to be significant. Innovations continued to accumulate, and their increase was transformed into a symbiosis of the old and new rank systems a decade later. The traditional ranks legitimately existed during Peter's reign, and after his death, the ranks continued to be used in Administrative Papers and in private documents. 


\section{Список литературы}

Агеева О. Г. Императорский двор России. 1700-1796 годы. М. : Наука, 2008. 380 с. Анисимов Е. В. Верхи русского общества начала Петровской эпохи // Правящая элита Русского государства IX - начала XVIII в. / отв. ред. А. П. Павлов. СПб. : Дмитрий Буланин, 2006. С. 470-497.

Богословский М. М. Петр I : Материалы для биографии : в 5 т. М. : ОГИЗ, 1948. T. $4.514 \mathrm{c}$.

Бушкович П. Петр Великий. Борьба за власть (1671-1725) / пер. Н. Л. Лужецкой. СПб. : Дмитрий Буланин, 2008. 604 с.

Грунд Г. Доклад о России в 1705-1710 гг. / пер. Ю. Н. Беспятых. М. ; СПб. : Ин-т рос. истории, $1992.138 \mathrm{c}$.

Двинской летописец / под ред. Б. А. Рыбакова, Я. С. Лурье, К. Н. Сербиной // ПСРЛ. Т. 33. Л. : Наука, 1977. С. 148-221.

Досифей. Летописец Соловецкий на четыре столетия, от основания Соловецкого монастыря до настоящего времени, то есть с 1429 по 1833 год. М. : Университет. тип., 1833. $177 \mathrm{c}$.

Захаров А. В. Информационно-поисковая полнотекстовая система «Боярские списки XVIII века». Челябинск, 2003-2020. URL: http://zaharov.csu.ru/bspisok.pl (дата обращения: 01.05.2020).

Захаров А. В. Государев двор Петра I : публикация и исследование источников разрядного делопроизводства. Челябинск : Изд-во Челяб. гос. ун-та, 2009. 447 с.

Захаров A. B. Комнатные стольники Петра I : Реконструкция состава и просопографическое исследование // Вестн. Перм. ун-та. Сер.: История. 2016. № 4. С. 85-99.

Куракин Б. И. Гистория о Петре I и ближних к нему людях // Рус. старина. Кн. 68. 1890. № 10. С. 229-260.

Лотман Ю. М., Успенский Б. А. Миф - имя - культура // Лотман Ю. М. Статьи по семиотике и топологии культуры : в 3 т. Таллин : Александра, 1992-1993. Т. 1. C. $58-75$.

Лукичев М. П. Боярские книги XVII века: труды по истории и источниковедению. М. : Древлехранилище, 2004. 538 с.

Медушевский A. Н. Боярские списки первой четверти XVIII века // Археографический ежегодник за 1981 г. М. : Наука, 1982. С. 158-163.

Миллер Г. Ф. Известие о дворянех Российских // Миллер Г. Ф. Сочинения по истории России : Избранное. М. : Наука, 1996. 448 с.

НИА СПбИИ РАН. Ф. 83. ОП. 1. Д. 3762.

Письма и бумаги императора Петра Великого : [в 13 т.]. СПб. : Гос. тип. ; М. : Наука, 1887-2003. Т. 11. Вып. 2. 743 с. Т. 13. Вып. 1. 480 с.

Походный журнал 1714 года. СПб. : [Б. и.], 1913. 160 с.

РГАДА. Ф. 9. ОП. 1. Д. 9; Отд. 2. Оп. 4. Д. 82; Ф. 154. Оп. 2. Д. 68; Ф. 199. Ед. хр. 130. Ч. 15. Д. 3; Ч. 16. Д. 6; Ф. 210. Оп. 1. Д. 11. Оп. 2. Д. 36, 41, 43, 45, 46, 49, 50, 52, 53, 55, 56, 58; Оп. 3. Д. 58, 60, 69, 70; Оп. 8. Д. 1098; Оп. 17. Д. 8; Ф. 248. Оп. 3. Кн. 95; Оп. 12. Д. 641; Ф. 286. Оп. 1. Д. 5, 7; Ф. 350. Оп. 3. Д. 1; Ф. 1209. Оп. 4/1. Д. 4719/17.

Руммель В. В., Голубцов В. В. Родословный сборник русских дворянских фамилий : в 2 т. СПб. : Изд. А. С. Суворина, 1887. Т. 2. 647 с.

Семевский М. И. Царица Прасковья. М. : Книга. 1989. 223 с.

Серов Д. О. Последние дьяки: из истории реформирования системы гражданских чинов России в первой четверти XVIII в. // Урал. ист. вестн. 2011. № 3. С. 64-72.

Соловьев С. М. Исторические письма // Соловьев С. М. Соч. : в 18 кн. М. : Мысль, 1995. Кн. 16. С. 353-404.

Crummey R. O. Peter and the Boyar Aristocracy, 1689-1700 // Canad.-Am. Slavic Studies. 1974. Vol. 8. No. 2. P. 274-287.

Crummey R. O. Aristocrats and Servitors. The Boyar Elite in Russia, 1613-1689. Princeton : Princeton Univ. Press, 1983. 338 p. 
Poe M. T. The Russian Elite in the Seventeenth Century : 2 Vols. Helsinki : Acad. Scientiarum Fennica, 2004. Vol. 1. The Consular and Ceremonial Ranks of the Russian "Sovereign's Court", 1613-1713. 469 p.

\section{References}

Ageeva, O. G. (2008). Imperatorskii dvor Rossii. 1700-1796 gody [Imperial Court of Russia. 1700-1796]. Moscow, Nauka. 380 p.

Anisimov, E. V. (2006). Verkhi russkogo obshchestva nachala Petrovskoi epokhi [Russian Elites of the Beginning of the Petrine Epoch]. In Pavlov, A. P. (Ed.). Pravyashchaya elita Russkogo gosudarstva IX - nachala XVIII v. St Petersburg, Dmitrii Bulanin, pp. 470-497.

Bogoslovskii, M. M. (1948). Petr I. Materialy dlya biografii [Peter the Great. Materials for Biography]. Moscow, OGIZ. Vol. 4. 514 p.

Bushkovitch, P. (2008). Petr Velikii. Bor'ba za vlast' (1671-1725) [Peter the Great. Struggle for Power (1671-1725)] / transl. by N. L. Luzhetskaya. St Petersburg, Dmitrii Bulanin. $604 \mathrm{p}$.

Crummey, R. O. (1974). Peter and the Boyar Aristocracy, 1689-1700. In Canad.-Am. Slavic Studies. Vol. 8. No. 2, pp. 274-287.

Crummey, R. O. (1983). Aristocrats and Servitors. The Boyar Elite in Russia, 16131689. Princeton, Princeton Univ. Press. 338 p.

Dosifei (1833). Letopisets Solovetskii na chetyre stoletiya, ot osnovaniya Solovetskogo monastyrya do nastoyashchego vremeni, to est's 1429 po 1833 god. [The Chronicle of the Solovetsky Islands for Four Centuries, from the Foundation of Solovetsky Monastery to the Present, from 1429 to 1833]. Moscow, Universitetskaya tipografiya. $177 \mathrm{p}$.

Grund, G. (1992). Doklad o Rossii v 1705-1710 gg. [Report on Russia in 1705-1710] / transl. by Yu. N. Bespyatykh. Moscow, St Petersburg, Institut rossiiskoi istorii. 138 p.

Kurakin, B. I. (1890). Gistoriya o Petre I i blizhnikh k nemu lyudyakh [History of Peter I and People Close to Him]. In Russkaya starina. Book 68. No. 10, pp. 229-260.

Lotman, Yu. M., Uspensky, B. A. (1992). Mif - imya - kul'tura [Myth - Name Culture]. In Lotman, Yu. M. Stat'i po semiotike i topologii kul'tury v 3 t. Tallin, Aleksandra. Vol. 1, pp. 58-75.

Lukichev, M. P. (2004) Boyarskie knigi XVII veka: trudy po istorii i istochnikovedeniyu [Boyar Books of the 17 $7^{\text {th }}$ Century: Studies in History and Source Studies]. Moscow, Drevlekhranilishche. 538 p.

Medushevskii, A. N. (1982). Boyarskie spiski pervoi chetverti XVIII veka [Boyar Lists of the First Quarter of the $18^{\text {th }}$ Century]. In Arkheograficheskii ezhegodnik za $1981 \mathrm{~g}$. Moscow, Nauka, pp. 158-163.

Miller, G. F. (1996). Izvestie o dvoryanekh Rossiiskikh [The Message of the Russian Nobility]. In Miller, G. F. Sochineniya po istorii Rossii. Izbrannoe. Moscow, Nauka. 448 p.

NIA SPbII RAN [Scientific and Historical Archive of St Petersburg Institute of the Russian Academy of Sciences]. Stock 83. List 1. Dos. 3762.

Pis'ma i bumagi imperatora Petra Velikogo [Letters and Papers of Emperor Peter the Great]. (1887-2003). Vol. 11. Iss. 2. St Petersburg, Gosudarstvennaya tipografiya. 743 p. Vol. 13. Iss. 1. Moscow, Nauka. 480 p.

Poe, M. T. (2004). The Russian Elite in the Seventeenth Century. 2 Vols. Helsinki, Acad. Scientiarum Fennica. Vol. 1. The Consular and Ceremonial Ranks of the Russian "Sovereign's Court", 1613-1713. 469 p. $160 \mathrm{p}$.

Pokhodnyi zhurnal 1714 goda [Campaign Diary 1714]. (1913). St Petersburg, S. n.

RGADA [Russian State Archive of Ancient Acts]. Stock 9. List 1. Dos. 9; Dpt. 2. List 4. Dos. 82; Stock 154. List 2. Dos. 68; Stock 199. Unified Repository. 130. Part 15. Dos. 3; Part 16. Dos. 6; Stock 210. List 1. Dos. 11. List 2. Dos. 36, 41, 43, 45, 46, 49, 50, 52, 53, 55, 56, 58; List 3. Dos. 58, 60, 69, 70; List 8. Dos. 1098; List 17. Dos. 8; Stock 248. List 3. Book 95; List 12. Dos. 641; Stock 286. List 1. Dos. 5, 7; Stock 350. List 3. Dos. 1; Stock 1209. List 4/1. Dos. 4719/17. 
Rummel', V. V., Golubtsov, V. V. (1887). Rodoslovnyi sbornik russkikh dvoryanskikh familii $v \quad 2$ t. [The Genealogical Collection of Russian Noble Families. 2 Vols.]. St Petersburg, Publ. by A. S. Suvorina. Vol. 2. 647 p.

Rybakov, B. A., Lurie, Ya. S., Serbina, K. N. (Eds.). (1977). Dvinskoi letopisets. In PSRL. Leningrad, Nauka. Vol. 33, pp. 148-221.

Semevskii, M. I. (1989). Tsaritsa Praskov'ia [Tsarina Praskov'ia]. Moscow, Kniga. $223 \mathrm{p}$.

Serov, D. O. (2011). Poslednie d'yaki: iz istorii reformirovaniya sistemy grazhdanskikh chinov Rossii v pervoi chetverti XVIII v. [The Last of the D'yaks: From the History of Reforms of the Civil Servants' System in Russia in the First Quarter of the $18^{\text {th }}$ Century]. In Ural'skii istoricheskii vestnik. No. 3, pp. 64-72.

Solovyov, S. M. (1995). Istoricheskie pis'ma [Historical Letters]. In Solov'ev, S. M. Sochineniya v 18 kn. Moscow, Mysl'. Book 16, pp. 353-404.

Zakharov, A. V. (2003-2020). Informatsionno-poiskovaya polnotekstovaya sistema "Boyarskiye spiski XVIII veka" [The "Boyar Lists of the $18^{\text {th }}$ Century" Database]. Chelyabinsk. URL: http://zaharov.csu.ru/bspisok.pl (accessed: 01.05.2020).

Zakharov, A. V. (2009). Gosudarev dvor Petra I. Publikatsiya i issledovanie istochnikov razryadnogo deloproizvodstva [Tsar's Court of Peter the Great. Publication and Research of the Razriadnyi Prikaz's Sources]. Chelyabinsk, Izdatel'stvo Chelyabinskogo gosudarstvennogo universiteta. $447 \mathrm{p}$.

Zakharov, A. V. (2016). Komnatnye stol'niki Petra Velikogo: rekonstruktsiya sostava i prosopograficheskoe issledovanie [Komnatnye Stol'niki of Peter the Great: Reconstruction of the Group and Prosopography]. In Vestnik Permskogo universiteta. Seriya: Istoriya. No. 4, pp. 85-99. 